\title{
大気浮遊粒子状物質の蛍光 $\mathbf{X}$ 線分析法による多元素定量と
}

\section{その正確さの評価}

\author{
安藤 仁 ${ }^{\mathrm{B} *}$, 井上 康明*, 佐藤 静雄 $^{*}$
}

\section{Multielement determination of suspended particulate matter by an X-ray fluorescence analysis and an analytical accuracy investigation}

\author{
Hitoshi ANDo ${ }^{(B)}$, Yasuaki InOuE ${ }^{*}$ and Sizuo $\mathrm{SATOH}^{*}$ \\ *Kawasaki Municipal Research Institute for Environmental Protection, 20-2, Tajima-cho, Kawasaki-ku, \\ Kawasaki-shi, Kanagawa 210
}

(Received 20 December 1996, Accepted 30 October 1997)

The analytical accuracy of suspended particulate matter (SPM) on a filter was investigated by a wavelength dispersive-type X-ray fluorescence spectrometer in both an empirical correction procedure method (EC) and a fundamental parameter method (FP). SPM samples were collected on a membrane filter with a low-volume air sampler. In this work, we analyzed 15 elements of 103 samples and investigated the accuracy of these quantitative methods in comparison with the measured values by AAS and IC. In the case of EC, a very good agreement could be confirmed for 10 elements $(\mathrm{Ca}, \mathrm{Ti}, \mathrm{V}, \mathrm{Cr}$, $\mathrm{Mn}, \mathrm{Fe}, \mathrm{Cu}, \mathrm{Ni}, \mathrm{Zn}, \mathrm{Pb}$ ). The correlation coefficient was 0.89 to 1.00 . Also the matrixeffect correction was made better a correlation for 4 elements $(\mathrm{Na}, \mathrm{Mg}, \mathrm{Cl}, \mathrm{K})$, Though $\mathrm{Al}$ was better without any matrix-effect correction. In case of $\mathrm{FP}$, the samples were treated as thin-layer samples, they were equal to EC in analytical accuracy, judging from the repeatability. On the other hand, samples were treated as bulk samples, the accuracy concerning which was aggravated. The average of the correlation coefficient made worse by 0.17 points. In addition, the management accuracy of the equipment, a sample for standardization of the instrument was prepared with poly-vinylalcohol and active carbone as a carrier. The coefficients of the variation of the X-ray intensities of the elements were less than $7.5 \%$ for measurements under 12 different dates during 12 months. This sample could be used for the standardization of the instrument for a long time, judging from the repeatability.

Keywords : X-ray fluorescence analysis; multi-elemental analysis; suspended particulate matter; empirical correction procedure method; fundamental parameter method.

\section{1 緒言}

大気浮遊粒子状物質 $($ SPM ) 中の元素分析において

*川崎市公害研究所：210 神奈川県川崎市川崎区田島町 20-2
蛍光 $\mathrm{X}$ 線分析法 $(\mathrm{XRF})$ は，採取した試料の化学的な 前処理を必要とせず迅速，簡便に直接分析を行えるた め, 有力な分析機器の一つとして利用されている. 定量 には単純な検量線法以外にも, 共存元素による励起吸収 の影響を補正するマトリックス補正法（EC 法）やファ 
Table 1 Elemental composition of synthetic calibration sample of XRF for SPM

(Unit: g)

\begin{tabular}{|c|c|c|c|c|c|c|c|c|c|c|c|c|}
\hline Categoly & Element & $\mathrm{Na}$ & $\mathrm{Mg}$ & $\mathrm{Al}$ & $\mathrm{Si}$ & & & & Carrier & Carrier & Carrier & $\begin{array}{c}\text { Total } \\
\text { amount }\end{array}$ \\
\hline \multirow[t]{3}{*}{1} & Compound & $\mathrm{NaNO}_{3}$ & $\mathrm{MgCl}_{2} \cdot 6 \mathrm{H}_{2} \mathrm{O}$ & $\mathrm{Al}_{2} \mathrm{O}_{3}$ & $\mathrm{SiO}_{2}$ & & & & $\left(\mathrm{NH}_{4}\right)_{2} \mathrm{SO}_{4}$ & $\begin{array}{c}\text { Active } \\
\text { carbone }\end{array}$ & $\begin{array}{l}\text { Poly-vinyl } \\
\text { alcohole }\end{array}$ & \\
\hline & Amount & 4.4475 & 0.1196 & 0.5687 & 2.7803 & & & & 9.7117 & 35.1462 & 30.1919 & 35.1462 \\
\hline & Element & $\mathrm{K}$ & $\mathrm{Ca}$ & $\mathrm{Ti}$ & $\mathrm{V}$ & $\mathrm{Cd}$ & & & & & & \\
\hline \multirow[t]{3}{*}{2} & Compound & $\mathrm{KNO}_{3}$ & $\mathrm{CaCO}_{3}$ & $\mathrm{TiO}_{2}$ & $\mathrm{~V}_{2} \mathrm{O}_{5}$ & $\mathrm{CdCO}_{3}$ & & & $\left(\mathrm{NH}_{4}\right)_{2} \mathrm{SO}_{4}$ & $\begin{array}{c}\text { Active } \\
\text { carbone }\end{array}$ & $\begin{array}{l}\text { Poly-vinyl } \\
\text { alcohole }\end{array}$ & \\
\hline & Amount & 0.0145 & 0.0325 & 0.0017 & 0.0002 & 0.0004 & & & 2.8694 & 8.7274 & 8.7377 & 8.7278 \\
\hline & Element & $\mathrm{Cr}$ & Mn & $\mathrm{Fe}$ & $\mathrm{Ni}$ & $\mathrm{Cu}$ & $\mathrm{Zn}$ & $\mathrm{Pb}$ & & & & \\
\hline \multirow[t]{2}{*}{3} & Compound & $\mathrm{K}_{2} \mathrm{Cr}_{2} \mathrm{O}_{7}$ & $\mathrm{MnO}_{2}$ & $\mathrm{Fe}_{2} \mathrm{O}_{3}$ & $\mathrm{NiO}$ & $\mathrm{CuCl}$ & $\mathrm{ZnO}$ & $\mathrm{PbO}$ & $\left(\mathrm{NH}_{4}\right)_{2} \mathrm{SO}_{4}$ & $\begin{array}{l}\text { Active } \\
\text { carbone }\end{array}$ & $\begin{array}{l}\text { Poly-vinyl } \\
\text { alcohole }\end{array}$ & \\
\hline & Amount & 0.0026 & 0.0023 & 0.0522 & 0.0000 & 0.0058 & 0.0000 & 0.0001 & 2.2007 & 14.6829 & 12.0133 & 14.6829 \\
\hline
\end{tabular}

ンダメンタルパラメーター法 (FP 法) 等が実用化され ている。しかし，EC 法で精度よく定量を行うためには 多くの標準試料を必要とし，FP 法は EC 法に比べ正確 さが劣るなよ゙一長一短がある1).

さて, いずれの定量法の場合においても, 校正用試料 を用いて X 線強度及びその測定誤差が許容範囲以内に あることを確かめ装置の校正を行うことが必須である.

JIS ではこの校正用試料を標準化試料 (calibration sample）と呼び「検量用試料（標準試料とも言う）を利 用することもできる」としている2).このように XRF では, 校正用試料を用いて機器の X 線強度を校正する ことが必須であるが，そのような精度管理の報告は少な い. その理由としては最近の XRF 装置の $\mathrm{X}$ 線強度変 動が少なくなったことも挙げられる. 一方, 従来のジメ チルジチオカルバミン酸のキレート沈殿法より調製され た校正用試料などでは，X 線の繰り返し照射により， 沈殿物がフィルターからはく離し, 破損しやすい問題も あった ( $^{6}$. 校正用試料は目的元素の濃度が既知で均質性 に優れていれば化学分析によって保証值の与えられた標 準物質である必要はなく，目的元素を混合した固体試料 が用いられることがある7).

そこで著者らは 19 種類の無機化合物と活性炭及びポ リビニルアルコールを用い, 調製が簡易で耐久性・安定 性に優れた SPM 分析に用いる校正用試料を開発し, 装 置の校正に使用してきた ${ }^{3)}$.

今回, 原子番号がチタン以下の軽元素も含め, SPM 中の多元素定量を行った.

結果を原子吸光分析 (AAS) 值等と比較し, マトリッ クス補正の効果や EC 法と FP 法の正確さを比較検討し た. 又, この校正用試料による精度管理のため, 連続及
び断続測定時における X 線強度の相対標準偏差 (RSD) を求め, 繰り返し精度の検討を行ったので合わせて報告 する.

\section{2 実験}

\section{$2 \cdot 1$ 装置及び測定条件}

XRF 装置は理学電機製 RIX-3000 全自動蛍光 X 線分 析装置を使用した．分光方式は波長分散型方式である. 分析線は鉄は $\mathrm{K} \beta$ 線, 鉛は $\mathrm{L} \alpha$ 線を, それ以外の元素 は $\mathrm{K} \alpha$ 線を使用した．更に強度の大きい分析線を得る ため管球, 分光結晶の条件を見直し, カリウムとカルシ ウムではクロム管球を用い，ケイ素は人工累積膜から成 る RX40 分光素子を用いた。

AAS 装置は日立ゼーマン偏光型原子吸光分析装置 180-80を用いた。

\section{$2 \cdot 2$ 多元素薄膜標準試料と校正用試料の調製}

多元素薄膜標準試料は, Spex 製 ICP 用 23 元素混合 標準溶液をセルロースフィルターに滴下, 乾燥し調製し た。校正用試料の調製のため, 定量目的元素を三つのグ ループに分類し, SPM 成分を参考に 19 種類の無機化 合物を計量し, 活性炭, ポリビニルアルコール及び再結 晶した硫酸アンモニウムを加えた。これらの含量を Table 1 に示す.これらを混ぜ合わせ, 純水を加え練り 合わせ，アルミリングで型どりをし $80^{\circ} \mathrm{C}$ でオーブン内 で 1 時間ほど乾固させブリケットを調製した。このま まだともろく，ち密さに欠けるため試料加圧成形機を用 いて $20 \times 10^{3} \mathrm{~kg} / \mathrm{cm}^{2}$ で加圧成形し, 校正用試料とし $た^{3)}$. 
Table 2 Correlation coefficient of calibration curve for XRF

\begin{tabular}{lccccccccccccccccc}
\hline \multicolumn{1}{c}{ Correction } & $\mathrm{Na}$ & $\mathrm{Mg}$ & $\mathrm{Al}$ & $\mathrm{Cl}$ & $\mathrm{K}$ & $\mathrm{Ca}$ & $\mathrm{Ti}$ & $\mathrm{V}$ & $\mathrm{Cr}$ & $\mathrm{Mn}$ & $\mathrm{Fe}$ & $\mathrm{Ni}$ & $\mathrm{Cu}$ & $\mathrm{Zn}$ & $\mathrm{Cd}$ & $\mathrm{Pb}$ \\
\hline Corrected $^{\mathrm{a})}$ & 0.91 & 0.93 & 0.98 & 1.00 & 0.88 & 0.99 & 1.00 & 0.94 & 0.97 & 1.00 & 0.99 & 0.95 & 0.99 & 0.97 & 1.00 & 0.99 \\
Uncorrected $^{\mathrm{b})}$ & 0.87 & 0.77 & 0.97 & 1.00 & 0.82 & 0.99 & 1.00 & 0.96 & 0.96 & 1.00 & 0.98 & 0.94 & 0.99 & 0.97 & 1.00 & 0.99 \\
\hline
\end{tabular}

$(n=90)$, a) matrix-effects correction, b) no matrix-effects correction

\section{$2 \cdot 3$ SPM の捕集}

SPM 試料は, 川崎市内の 4 地点において $10 \mu \mathrm{m}$ カッ トローボリュームエアサンプラーにメンブランフィル ター(富士フィルム FM-120 ポアサイズ $1.2 \mu \mathrm{m}$ ) 及び 石英繊維製フィルター（Pallflex 2500QAT）を装着し， 毎分 201 の流量で同時に 3 日閒捕集した。捕集は 1 か 月間隔で 2 年間ほぼ続けた。.メンブランフィルター捕 集試料はXRF を行った後, 酸分解(フッ化水素酸，硝 酸一過塩素酸分解）し，金属成分を AASにより分析し た，塩化物イオンは，石英繊維製フィルター捕集試料を 純水で超音波抽出後, イオンクロマトグラフィー (IC) により定量した。

\section{3 結果亡考察}

\section{3・1 EC 法における共存元素からの影響による補正 值の決定}

$\mathrm{EC}$ 法に用いる含有量 $\left(\mu \mathrm{g} / \mathrm{cm}^{2}\right)$ に対するX 線強度 (kcps) で表される検量線の作成のため，2·2 の多元素 薄膜標準試料並びに MicroMatter 製標準物質蒸着薄膜 の測定を行った．更に大気中の SPM を捕集し，X 線強 度測定後，AAS を行い定量值をデータとして加えた (デー夕数 90).

検量線式を式（1）のように二次式あるいは一次式と した．今回は多元系の補正式を式 $(2)$ のように設定し， 存在比の多い共存元素 $(\mathrm{Na}, \mathrm{Al}, \mathrm{Si}, \mathrm{K}, \mathrm{Ca}, \mathrm{Fe}, \mathrm{Cl})$ を対 象にマトリックス効果 (励起吸収効果) 及び隣接分析線 の重なりの影響の検討を行い，各補正係数を算出し $\hbar^{4)}$.

$$
W_{\mathrm{i}}=a \hat{X} i^{2}+b \hat{X} i+c
$$

$\hat{X}_{\mathrm{i}}$ : 定量元素 $(i)$ の強度值 $(\mathrm{kcps})$

$W_{\mathrm{i}}$ : 定量元素 $(i)$ の未補正含量 $\left(\mu \mathrm{g} / \mathrm{cm}^{2}\right)$

$a, b, c:$ 検量線の各係数

$$
\begin{aligned}
& \hat{W}_{\mathrm{i}}=W_{\mathrm{i}}\left(1+d_{\mathrm{j}} X_{\mathrm{j}}\right)+l_{\mathrm{j}} X_{\mathrm{j}} \\
& \hat{W}_{\mathrm{i}}: \text { 定量元素 }(i) \text { の補正含量 }\left(\mu \mathrm{g} / \mathrm{cm}^{2}\right) \\
& X_{\mathrm{j}}: \text { 共存元素 }(j) \text { の強度值 }(\mathrm{kcps}) \\
& d_{\mathrm{j}}: \text { 励起吸収補正係数 } \\
& l_{\mathrm{j}}: \text { 重なり補正係数 }
\end{aligned}
$$

10 元䒺について含有量に対する X 線強度を調べ，そ の検量線の相関係数を Table 2 に示す。マトリックス 効果及び隣接分析線の重なりの補正を行った場合，ナト リウム，マグネシウム及びカリウムなど多くの元素で相 関性が向上した。その結果，相関係数は調べたすべての 元素で 0.88 以上であり，検量線上付近に集中している ことが分かる．このように補正により精度の向上が行え ることが分かった。

\section{3 •2 SPM に対する XRF，AAS 並びに IC の適用範} 囲

本研究ではXRFによる標準等の濃度既知試料の分

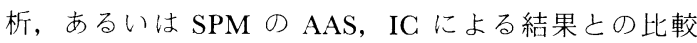
で，正確さの評価を行う。その目的で利用した SPM 中 の元素存在量の最大, 最小及び平均値, 並びに.XRF の 定量下限を Table 3 に示す。表中の結果のうち， $\mu \mathrm{g} /$ $\mathrm{cm}^{2}$ での表示はXRF，w\% での表示は塩素については IC，そのほかの元素はAAS の結果である.

$\mathrm{XRF}$ の検出下限は, 蛍光 $\mathrm{X}$ 線のピーク強度の下のバ ックグラウンド強度の平均值の平方根の 3 倍に相当之 する含量と定義した．又，スペクトルの形状から定義で きない元素についてはNDとしたが，検出下限は近接 原子番号の元素のそれに近いと考えられる．XRFにつ いては，適用元素に対する評価を行った。すべての試料 で定量值が定量下限より大きい元素を ++ とし 10 元 素が該当した。 カドミウムを除くほかの 5 元素でも， いずれの検出下限が平均值之同等か大きく，研究の目的

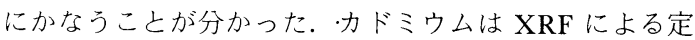
量下限も最大値より大きく, 今後の評価からは除外する こととした．定量結果から，それぞれの元素の存在量の 範囲は十分広く, SPM 中の代表的な存在量の範囲を十 分に包含できることが分かかる。

\section{3・3 EC による SPM 中の多元素同時定量の正確さ の評価}

校正用試料を用い XRF 装置の校正を行った後, 空試 験を含めて 103 個の SPM 捕集試料を XRF 分析し, 共 存元素によるマトリックス補正を行い，その影響を 15 
Table 3 Range of elemental abundance of SPM used evaluation of XRF

\begin{tabular}{|c|c|c|c|c|c|c|c|c|c|c|c|c|c|c|c|c|}
\hline Element & $\mathrm{Na}$ & $\mathrm{Mg}$ & $\mathrm{Al}$ & $\mathrm{Cl}$ & $\mathrm{K}$ & $\mathrm{Ca}$ & $\mathrm{Ti}$ & V & $\mathrm{Cr}$ & Mn & $\mathrm{Fe}$ & $\mathrm{Ni}$ & $\mathrm{Cu}$ & $\mathrm{Zn}$ & $\mathrm{Cd}$ & $\mathrm{Pb}$ \\
\hline \multicolumn{17}{|c|}{$\left[\mathrm{XRF} / \mu \mathrm{g} \mathrm{cm}^{-2}\right]$} \\
\hline Maximum & 15.3 & 7.8 & 31.6 & 106.8 & 10.8 & 37.8 & 1.38 & 0.32 & 0.84 & 1.04 & 36.4 & 0.45 & 1.20 & 6.35 & 0.02 & 2.05 \\
\hline Minmum & 0.7 & 0.2 & 0.7 & 0.2 & 0.3 & 0.7 & 0.05 & 0.02 & 0.02 & 0.04 & 1.7 & ND & 0.03 & 0.30 & ND & 0.11 \\
\hline Average & 6.0 & 1.8 & 7.4 & 14.6 & 2.9 & 6.7 & 0.43 & 0.12 & 0.15 & 0.36 & 11.9 & 0.14 & 0.33 & 3 & - & 0.73 \\
\hline $\begin{array}{l}\text { Detection } \\
\text { limit }\end{array}$ & 0.6 & 0.4 & ND & 0.3 & 0.3 & ND & ND & 0.06 & ND & 0.01 & ND & ND & ND & 0.04 & ND & 0.08 \\
\hline $\begin{array}{c}\text { Estimate } \\
\text { AAS, w\%] }\end{array}$ & ++ & + & ++ & + & ++ & ++ & + & + & ++ & ++ & ++ & + & ++ & ++ & - & ++ \\
\hline Maximum & 18.4 & 7.85 & 7.46 & $10.92^{\dagger}$ & 5.34 & 8.18 & 0.256 & 0.120 & 0.203 & 0.270 & 13.42 & 0.173 & & 2.57 & 0.050 & 1.16 \\
\hline Minmum & 0.3 & 0.16 & 0.37 & $0.01^{\dagger}$ & 0.25 & 0.36 & 0.003 & 0.001 & 0.002 & 0.014 & 0.84 & 0.001 & 0.020 & 0.09 & ND & 0.02 \\
\hline Average & 2.6 & 0.94 & 1.78 & $3.50^{\dagger}$ & 1.20 & 2.00 & 0.085 & 0.021 & 0.041 & 0.089 & 3.58 & 0.036 & 0.092 & 0.67 & 0.008 & 0.22 \\
\hline
\end{tabular}

${ }^{\dagger}$ Detected by IC.

Table 4 Correlation and regression coefficient between analytical result of XRF $\left(\mathrm{EC}^{\mathrm{a})}\right)$ and AAS

\begin{tabular}{|c|c|c|c|c|c|c|c|c|c|c|c|c|c|c|c|c|}
\hline Correction & & $\mathrm{Na}$ & $\mathrm{Mg}$ & $\mathrm{Al}$ & $\mathrm{Cl}^{\mathrm{b})}$ & $\mathrm{K}$ & $\mathrm{Ca}$ & $\mathrm{Ti}$ & V & $\mathrm{Cr}$ & $\mathrm{Mn}$ & $\mathrm{Fe}$ & $\mathrm{Ni}$ & $\mathrm{Cu}$ & $\mathrm{Zn}$ & $\mathrm{Pb}$ \\
\hline \multirow[t]{3}{*}{ (1) Correctec $^{\text {c) }}$} & $r$ & 0.85 & 0.78 & 0.87 & 0.95 & 0.84 & 0.99 & 0.91 & 0.94 & 0.89 & 1.00 & 0.99 & 0.89 & 0.98 & 0.96 & 0.99 \\
\hline & $a$ & 1.22 & 0.98 & 0.79 & 0.95 & 1.00 & 1.00 & 0.95 & 0.73 & 0.99 & 1.00 & 1.07 & 0.86 & 1.01 & 0.99 & 1.05 \\
\hline & $b$ & 0.03 & 0.09 & 0.00 & 0.00 & 0.11 & 0.06 & 0.00 & -0.00 & 0.00 & 0.00 & 0.00 & 0.00 & 0.00 & -0.00 & 0.00 \\
\hline \multirow[t]{3}{*}{ (2) Uncorrected ${ }^{\mathrm{d})}$} & $r$ & 0.83 & 0.72 & 0.88 & 0.95 & 0.97 & 0.98 & 0.91 & 0.94 & 0.90 & 0.99 & 0.99 & 0.90 & 0.98 & 0.96 & 0.99 \\
\hline & $a$ & 1.94 & 2.78 & 0.93 & 1.32 & 1.28 & 0.97 & 0.95 & 0.76 & 1.01 & 1.08 & 1.05 & 0.85 & 1.00 & 1.17 & 1.07 \\
\hline & $b$ & -0.02 & 0.06 & 0.00 & 0.00 & 0.05 & 0.07 & 0.00 & -0.00 & 0.00 & 0.00 & 0.00 & 0.00 & 0.00 & -0.02 & 0.00 \\
\hline
\end{tabular}

$(\mathrm{XRF})=a \times(\mathrm{AAS})+b \quad(n=103), r$ : correlation coefficient; $a:$ regression coefficient $; b$-axis intercept; a) empirical correction procedure method, b) measured by IC, c) matrix-effects correction, d) no matrix-effects correction

元素について AAS 及び IC の結果と比較した. その結 果を Table 4 に示す.

補正を行わない場合（2)）は，マンガン，鉄，銅，鉛 では相関係数, 回帰係数とも 1 に近く, $y$ 切片も 0 に 近い, 比較的良い相関で定量ができている。しかし，ナ トリウム, マグネシウムについては, 回帰係数がそれぞ れ 1.9 よ 2.8 のうに1より外れた.

補正を行った場合 (1) は, マグネシウムは相関係数 は 0.78 でやや低いものの, 他の元素は相関係数は 0.85 以上で有意な差は認められなかった。回帰係数もナトリ ウム, マグネシウムで大幅な改善が見られ，それぞれ 1.2, 0.99 亡なった. 原子番号がチタンより大きい元素 については回帰直線が原点近傍を通り, 定量值が回帰直 線上付近に集まる非常に良い一致を確認できた。

塩素は, IC の結果との比較を行ったが, 回帰係数が 1 に近くなり，分析值の多くが回帰直線上付近に集まる 良い一致であった. 本結果はフィルタ一上の SPM 試料 でもマトリックス補正の効果によって塩化物イオン值を 十分に定量できることが分かった初めての例である.

アルミニウムについては, 補正を行わない場合のほう
が相関係数，回帰係数が共に若干 1 に近づく結果とな った.アルミニウムについては, AAS での感度が低く, 今後の検討にしたい.

\section{3・4 FP 法の SPM への適用}

現在, 多くの標準試料を必要としない FP 法を用いた 定量分析が広く実用化されているが，FP 法は正確さで EC 法に比べ劣ると一般に言われている ${ }^{4)}$. 一方，実際 のSPM を用いて定量の正確さを検討した例は少ない. そこで，捕集した SPM 試料より得られた実測強度を $\mathrm{FP}$ 法による理論 X 線強度と対比させた.

蛍光 $\mathrm{X}$ 線の理論強度式の基本式は, 入射 $\mathrm{X}$ 線による 励起によって発生する一次蛍光 $\mathrm{X}$ 線強度と, 共有元素 の一次蛍光 $\mathrm{X}$ 線によって励起され発生する二次蛍光 $\mathrm{X}$ 線強度の和で近似し, 波長の強度分布や吸収効果を含ん だ計算式となる。この式を薄膜試料の場合は層内・層間 の励起吸収を考慮した基本式を忍用し, 密度・厚さなよ゙ の化学組成情報をパラメーターとして加える. 一方, バ ルク (無限厚) 試料の場合は試料深さ方向に無限大まで 積分する5). 
Table 5 Coefficieints of variation of repeatability of samples for standardization

\begin{tabular}{|c|c|c|c|c|c|c|c|c|c|c|c|c|c|c|c|c|c|c|}
\hline $\begin{array}{c}\text { Sample for } \\
\text { Standardization }\end{array}$ & Measurement & $\mathrm{Na}$ & $\mathrm{Mg}$ & $\mathrm{Al}$ & $\mathrm{Si}$ & $\mathrm{Cl}$ & $\mathrm{K}$ & $\mathrm{Ca}$ & $\mathrm{Ti}$ & V & $\mathrm{Cr}$ & $\mathrm{Mn}$ & $\mathrm{Fe}$ & $\mathrm{Ni}$ & $\mathrm{Cu}$ & $\mathrm{Zn}$ & $\mathrm{Cd}$ & $\mathrm{Pb}$ \\
\hline $\begin{array}{l}\text { Sample preparared } \\
\text { by molding pressure } \\
\text { into a briquet }\end{array}$ & Continuous $^{\text {a) }}$ & 0.04 & 0.06 & 0.23 & 0.04 & 0.13 & 0.01 & 0.05 & 0.22 & 0.36 & 0.10 & 0.33 & 0.09 & 0.09 & 0.07 & 0.01 & 0.26 & 0.10 \\
\hline $\begin{array}{l}\text { Sample preparared } \\
\text { by molding pressure } \\
\text { into a briquet }\end{array}$ & Intermittent $^{\text {b) }}$ & 5.01 & 4.09 & 6.55 & 2.43 & 2.82 & 2.43 & 3.52 & 1.01 & 7.48 & 2.11 & 2.32 & 3.69 & 0.95 & 5.46 & 6.88 & 1.38 & 1.04 \\
\hline $\begin{array}{l}\text { Sample preparared } \\
\text { by vacuum deposi- } \\
\text { tion metals }\end{array}$ & Intermittent & 5.46 & 3.58 & 7.88 & 4.45 & 2.75 & 2.05 & 3.40 & 4.41 & 1.79 & 1.69 & 1.49 & 1.78 & 2.77 & 2.08 & - & 0.23 & 2.12 \\
\hline
\end{tabular}

a) 3 times during 9 minutes, b) 12 differents dates during 12 months

理論 X 線強度の計算は, FP 法では元素が分析対象 か否かにかかわらず全元素を設定して分析するのが原則 である.しかし，大気中 SPM にはあらゆる元素が存在 しこののずてを設定するのは非常に困難である。そこ で今回は含有率 $(\mathrm{wt} \%)$ が既知の元素はできるだけ校 正用武料のデータとして組み込むことにして，16 元素 の含量を含有率に換算し, 同時に測定していた炭素成分 の含有率もデータとして加えた。理論 X 線頻度を XRF 装置内蔵のプログラムを用いて算出するに当たり, 測定 対象物質を単純な薄層試料 (単層試料) として取り扱 い, 校正用試料を 20 種（11) 及び 5 種を用いた場合 (2)), 又測定対象物質をバルク試料 (無限厚試料) とし て取り扱い，校正用試料を 20 種で算出する (3) 三つ の方法で正確さを検討した，但し，単純な薄層試料とし て取り扱った場合, メンブランフィルターは基板（ベー ス）とし，試料の厚さを付着重量として設定した。

\section{3 .5 校正用試料の安定性}

校正用試料のデー夕を用いる EC 法では, 用いる校 正用試料の X 線照射に対する十分な安定性が必要であ る.そこで今回，作製した校正用試料を利用して精度管 理を実施するに当たり, 連続・断続の繰り返し測定を行 い校正用試料自身の安定性を検討した。校正用試料の連 続・断続繰り返し測定時の, X 線強度 RSD 及び MicroMatter 製標準物質蒸着薄膜の断続測定時の RSD を Table 5 に示す.

連綕繰り返し精度を調べるため, 3 分間隔で連続 3 回 という短時間間隔で測定を行った。いずれの元素につい ても X 線強度の RSD は $0.01 \%$ から $0.364 \%$ となり極 めて良好な結果が得られた。 その後も同条件で測定を行 ったが相対標準偏差は $0.4 \%$ 以下であった. 又, 断続繰 り返し精度を調べるため, 約 1 年間に 12 回(約 1 月間 隔）という断続的な測定を行った.ほとんどの元素で $\mathrm{X}$ 線強度の RSD は数\%であった. 標準物質蒸着薄膜
の場合でも同様な測定を行ったが， $0.2 \%$ から $7.9 \%$ で あった。

断続的な測定における変動は調べたすべての元素で見 られることから, XRF 分析装置自身の器差と推定され, 今回作製の校正用試料自身の変動ではないと推定され る. 又, 破損・変形・変質を認めず長期間にわたって安 定に使用できた，以上から，本試料は XRF の校正用試 料として良好に使用できた数少ない例となった。

\section{$3 \cdot 6$ FP 法による SPM 中の多元素同時定量の正確 さの評価}

$\mathrm{EC}$ 法と同様に空試験を含めて 89 個の SPM 捕集試 料について, 理論 X 線強度と対比させて定量を行い, 15 元素について AAS 及び IC の結果と比較した。その 結果を Table 6 に示す.

測定対象物質を薄層試料として取り扱い, 校正用試料 を 20 種用いた場合（1）は，標準試料を5 種用いた場 合 (2) と比較して相関係数や回帰係数の点で優れた結 果が得られた.ナトリウム，マグネシウム以外は相関係 数は 0.8 以上でよく一致した結果が認められ, EC 法之 比較してもそん色のない正確さで定量ができた。バナジ ウム, クロム, ニッケルについては最低含有率が 0.03 $\mathrm{wt} \%$ 未満であり, 定量下限の限界に近い含有率の試料 も含まれており，そのため相関係数が 0.9 以下になった と考えられる. しかしこれらの元素の場合でも, 校正用 試料を増やすと, 相関係数, 回帰係数とも改善が見られ た。通常，多層膜試料や鉱石含量の分析において用いら れる FP 法では, 5 種程度の標準試料から理論 $\mathrm{X}$ 線強 度を求め定量を行うこともあるが, フィル夕一上の SPM の定量においては，5種では不十分な結果だった と言える.

又, 測定対象物質をバルク試料として取り扱った場合 (3) は，標準試料を 20 種も使用したにもかかわらず 相関係数は平均で約 0.17 低くなり, 特に EC 法でよく 
Table 6 Correlation and regression coefficient between analytical result of XRF and AAS

\begin{tabular}{|c|c|c|c|c|c|c|c|c|c|c|c|c|c|c|c|c|c|}
\hline Type & $\begin{array}{l}\text { Number of } \\
\text { reference } \\
\text { samples }\end{array}$ & & $\mathrm{Na}$ & $\mathrm{Mg}$ & $\mathrm{Al}$ & $\mathrm{Cl}$ & $\mathrm{K}$ & $\mathrm{Ca}$ & $\mathrm{Ti}$ & $\mathrm{V}$ & $\mathrm{Cr}$ & $\mathrm{Mn}$ & $\mathrm{Fe}$ & $\mathrm{Ni}$ & $\mathrm{Cu}$ & $\mathrm{Zn}$ & $\mathrm{Pb}$ \\
\hline \multirow[t]{3}{*}{ (1) Thin-layer type } & & $r$ & 0.44 & 0.75 & 0.86 & 0.96 & 0.97 & 0.98 & 0.92 & 0.88 & 0.88 & 0.99 & 0.98 & 0.88 & 0.97 & 0.95 & 0.98 \\
\hline & 20 & $a$ & 1.06 & 1.08 & 1.09 & 0.93 & 1.01 & 1.02 & 0.91 & 0.70 & 1.03 & 1.00 & 1.12 & 2.27 & 1.01 & 1.00 & 1.07 \\
\hline & & $b$ & 0.00 & 0.05 & 0.00 & 0.00 & 0.00 & 0.10 & 0.00 & -0.00 & 0.01 & 0.00 & 0.00 & 0.00 & 0.00 & 0.00 & 0.00 \\
\hline \multirow[t]{3}{*}{ (2) Thin-layer type } & & $r$ & 0.50 & 0.78 & 0.86 & 0.66 & 0.98 & 0.93 & 0.92 & 0.88 & 0.83 & 1.00 & 0.98 & 0.88 & 0.98 & 0.95 & 0.98 \\
\hline & 5 & $a$ & 1.39 & 1.10 & 1.12 & 0.49 & 0.90 & 1.38 & 0.94 & 0.73 & 0.76 & 0.97 & 1.15 & 2.74 & 0.97 & 1.00 & 1.08 \\
\hline & & $b$ & 0.00 & 0.08 & 0.00 & 0.00 & 0.00 & -0.06 & 0.00 & -0.00 & 0.01 & 0.00 & 0.00 & 0.00 & 0.00 & 0.00 & 0.01 \\
\hline \multirow[t]{3}{*}{ (3) Bulk type } & & $r$ & 0.44 & 0.73 & 0.65 & 0.91 & 0.76 & 0.80 & 0.74 & 0.63 & 0.74 & 0.85 & 0.73 & 0.58 & 0.74 & 0.61 & 0.66 \\
\hline & 20 & $a$ & 0.70 & 0.67 & 0.87 & 0.72 & 0.88 & 0.57 & 0.73 & 0.40 & 0.67 & 0.43 & 0.83 & 0.83 & 0.62 & 0.58 & 0.71 \\
\hline & & $b$ & 0.00 & 0.13 & 0.00 & 0.00 & 0.00 & 0.40 & 0.00 & 0.00 & 0.01 & 0.02 & 0.00 & 0.01 & 0.00 & 0.00 & 0.00 \\
\hline
\end{tabular}

$(\mathrm{XRF})=a \times(\mathrm{AAS})+b(n=89), r$ : correlation coefficient $; a$ : regression coefficient; $b: y$-axis intercept

一致したチタン以上の重元素はその低下が大きかった. 又，相関係数が 0.8 以上でもその回帰係数は 1 より大 きく離れており，両分析值で約 $30 \%$ 以上の相違があっ た。

本結果は, 大気中 SPM 試料を薄膜試料として取り扱 い, 20 個程度の標準物質を用いて理論 $\mathrm{X}$ 線強度を求め れば，FP 法を利用しても十分な正確さを持って多元素 定量ができることを検証した数少ない例となった。

$$
4 \text { ま と め }
$$

波長分散型 XRF 装置による SPM 中の多元素定量値 の正確さを EC 法及び FP 法で検討した。 EC 法ではチ タン以上の元素については非常に正確に定量でき，ナト リウム, マグネシウムについてはマトリックス補正を行 わない場合は相関性が悪かった。FP 法は測定対象物質 を薄層試料として取り扱い，標準試料を 20 種用いた場 合はナトリウム，マグネシウム以外は相関係数は 0.8 以 上で, EC 法に比べて同様の分析正確さが得られるが, ある程度の個数の標準物質を用意したほうがより良い正 確さで定量分析できることが分かった. 又, バルク試料 として取り扱った場合は, 相関係数は平均で約 0.17 低 くなり，特に重元素はその低下が大きかった．以上よ り, 大気中 SPM 試料を薄膜試料として取り扱い, 20 種程度の標準物質を用いて理論 $\mathrm{X}$ 線強度を求めれば,
$\mathrm{FP}$ 法を利用しても十分な正確さを持って多元素定量が できることが検証できた。

装置の $\mathrm{X}$ 線強度校正のための校正用試料についての 検討も行った。今回作製の校正用試料自身の変動は無視 でき，長期間にわたって軽元素を含む XRF の強度校正 用試料として使用できることが分かった．

最後に，今回は 100 個以上の数多くの試料を分析す ることにより，XRF の正確さを検討したが粒径効果な ビは無視しており，正確さ向上のために更なる補正法の 検討が必要であると考える. 又，今後，揮散してしまう ため比較できなかったケイ素などについても定量の正確 さの検討を行うつもりである.

\section{文献}

1) 大野勝美: X 線分析の進歩, 8,91 (1976).

2) JIS K 0119, 蛍光 X 線分析方法通則 (1987).

3) 安藤 仁, 井上康明, 井上俊明, 佐藤静雄: 川崎 市公害研究所年報, 22, 23 (1996).

4）安部忠廣, 成田正尚, 佐伯正夫：X 線分析の進 歩, 17, 143 (1976).

5) D. Laguitton, M. Mantler: Adv. X-Ray Anal., 20, 515 (1977).

6）水見康二，村松富美雄：大気污染研究，10，135, (1975).

7）JIS G 1256, 鉄及び鋼の蛍光 $\mathrm{X}$ 線分析方法 (1982). 


\section{要 旨}

波長分散型の蛍光 X 線分析法 (XRF) に上る大気浮遊粒子状物質の多元素定量における正確さを, マトリックス補正（EC）法及びファンダメンタルパラメーター（FP）法で検討した例は少ない．今 回, 多数の試料中の 16 元素の同時定量を行い, 結果を原子吸光法, イオンクロマトグラフ法と比較 し, マトリックス補正の効果や EC 法と FP 法の定量分析の正確さなどに関して多くの知見を得た。 EC 法ではチタン以上の元素については非常に正確に定量でき，ナトリウム，マグネシウムについては マトリックス補正を行わない場合は相関性が悪かった。 又, 測定物質を薄膜試料として取り扱えば FP 法でも EC 法と比べても同じ正確さで定量できるが，バルク試料として取り扱った場合，正確さが悪 化した．加えて，活性炭及びポリビニルアルコールなどから作製した校正用試料を用いて装置の精度管 理を行い，装置の校正試料として使用できることも分かった。 